\title{
Strength Analysis on Airplane Fuselage Structure Stringer
}

\author{
Dwi Hartini \\ Program Studi Teknik Penerbangan, Sekolah Tinggi Teknologi Adisutjipto \\ Email : mdwihartini@ymail.com
}

Received: 7 Oktober 2019; Accepted : 16 Maret 2020; Published : 1 November 2020

\begin{abstract}
ABSTRAK
Fuselage adalah struktur utama pesawat yang dirancang untuk mengakomodasi kru, penumpang, dan kargo. Fuselage pesawat modern adalah konstruksi semi-monocoque. Struktur semi-monocoque sangat efisien, memiliki strength to weight ratio yang tinggi, dan memiliki fleksibilitas desain dan dapat menahan kegagalan lokal tanpa kegagalan total melalui redistribusi beban. Salah satu pembebanan pada fuselage adalah tekanan kabin. Pada pengoperasian pesawat secara terus menerus akibat tekanan kabin, damage bisa terjadi pada fuselage, misalnya pada bagian stringer. Tipe repair untuk menangani kasus damage pada stringer perlu dilakukan analisis. Penelitian ini bertujuan untuk mengetahui pengaruh ketebalan angle dan variasi fastener terhadap kekuatan struktur repair stringer. Tahap analisis dengan melakukan pemodelan 3D dengan software CATIA. Simulasi analisis struktur berupa luaran tegangan dan menghitung Margin of Safety. Semakin tebal angle dan semakin banyak jumlah fastener pada area web dan flange yang digunakan, maka nilai tegangan yang terjadi pada tiap-tiap variasi akan menurun. Struktur pemodelan ini aman terhadap pembebanan pressure.
\end{abstract}

Kata Kunci : Kekuatan Struktur, Stringer, Repair, Margin of Safety

\begin{abstract}
Fuselage is an airplane main body structure designed for accommodating the crew, passengers, and cargo. The fuselage of a modern aircraft is a semi-monocoque construction. Semi-monocoque structure is very efficient, it has a high strength to weight ratio, and it has design flexibility and can withstand local failure without total failure through load redistribution. One of the loading on fuselage is cabin pressure. In continuous operation airplane due to cabin pressure, damage often occur in the fuselage, for example on the stringer. Type of repair to deal with cases of damage to stringer needs to be analyzed. This study aims to determine the effect of angle thickness and fastener variations on the strength of repair stringer structure. The analysis stage by $3 D$ modeling with CATIA software. Simulation of structural analysis in the form stress and calculating the Margin of Safety. The thicker of angle and the more number of fasteners in the web area and the flange used in the repair, the stress that occurs in each variation will decrease. Modeling the structure is safe against pressure loading. Keywords : Strength of the Structure, Stringer, Repair, Margin of Safety
\end{abstract}

\section{PENGANTAR}

Fuselage adalah struktur utama pesawat yang dirancang untuk mengakomodasi kru, penumpang, dan kargo. Fuselage pesawat modern adalah cangkang kaku yang biasa disebut konstruksi semi-monocoque. Struktur semi-monocoque sangat efisien, memiliki strength to weight ratio yang tinggi, dan memiliki fleksibilitas desain dan dapat menahan kegagalan lokal tanpa kegagalan total melalui redistribusi beban. Fuselage sebagai beam terdiri dari elemen longitudinal (longeron dan stringer), elemen transversal (frame dan bulkhead) dan skin eksternal. [1].

Salah satu pembebanan pada fuselage adalah tekanan kabin. Pada pengoperasian pesawat secara terus menerus akibat tekanan kabin, damage bisa terjadi pada fuselage, misalnya pada bagian stringer. Oleh karena itu perlu dilakukan repair untuk menjamin struktur tersebut layak digunakan. Petunjuk untuk melaksanakan repair sudah tercantum dalam Structure Repair Manual (SRM). Dalam ketentuan SRM tidak dijelaskan mengapa struktur yang mengalami kerusakan harus direpair seperti petunjuk yang telah ditetapkan, tetapi bila repair dilaksanakan sesuai panduan tersebut, keamanan struktur akan terjamin. Tipe repair untuk menangani kasus damage perlu dilakukan analisis untuk mengetahui kekuatan strukturnya.

Penelitian mengenai struktur fuselage sudah banyak dilakukan, baik dalam hal mendesain maupun menganalisis kekuatan struktur fuselage tersebut. Namun banyak penelitian sebelumnya yang hanya menentukan respon struktur berupa tegangan maksimum dari hasil analisis tegangan untuk menentukan kekuatan strukturnya. Analisis struktur dan optimization material pada fuselage dilakukan menggunakan Finite Element Analysis (FEA), paduan aluminium dapat diganti dengan material komposit tanpa mempengaruhi strength dan stress intensity factor characteristics pada fuselage. [2]. Penelitian selanjutnya adalah untuk merancang fuselage pesawat masa depan yang canggih. Menggunakan fungsi objektif yang berbeda-beda, 
diperlihatkan bahwa desain bagian fuselage pesawat adalah peka terhadap persyaratan dari berbagai disiplin ilmu. [3]. Penelitian juga dilakukan pada fuselage splice joint. Dalam analisis ini, simulasi distribusi tegangan dan deformasi pada joint seperti bonded, riveted, dan hybrid joints telah sukses dilakukan. Ditemukan bahwa hybrid joints yang dirancang dengan baik sangat efisien jika dibandingkan dengan jenis bonded joint dan riveted joints karena menyebabkan deformasi dan distribusi tegangan yang efisien. [4]. Fuselage floor beam analysis design dilakukan menggunakan Ansys10.0. Nilai perpindahan diperoleh. Ketika nilai perpindahan Ansys ini dibandingkan dengan nilai analitis, ditemukan bahwa nilainya dekat satu sama lain. [5]. Penelitian juga dilakukan dengan menganalisis elemen hingga pada struktur fuselage frame berbahan komposit menggunakan Finite Element Analysis (FEA). E-glass dan Carbon fabric memberikan hasil lebih baik atau mendekati dengan Aluminum Al-7075. [6]. Penelitian selanjutnya terhadap struktur fuselage dengan konstruksi semi monocoque. Melalui penggunaan model pesawat yang disederhanakan, ditemukan konvergensi hasil classical hand analysis dan FEA.[7].

Pada penelitian ini melakukan analisis kekuatan struktur stringer pada fuselage pesawat. Dalam hal ini diambil studi kasus struktur stringer pada fuselage pesawat Boeing 737-300 yang mengalami damage sesuai ketentuan SRM. Penelitian ini bertujuan untuk mengetahui pengaruh ketebalan angle dan variasi fastener terhadap kekuatan struktur repair stringer. Untuk menentukan kekuatan strukturnya, dilakukan dengan analisis tegangan (stress analysis) terlebih dahulu kemudian dilanjutkan dengan analisis kekuatan struktur (strength analysis) dengan menghitung nilai Margin of Safety.

\section{METODE PENELITIAN}

Metode yang digunakan dalam penelitian ini adalah Finite Element Method (FEM). Penelitian ini dimulai dengan pemodelan dan analisis struktur menggunakan software CATIA, kemudian dari hasil analisis akan ditentukan respon struktur dalam bentuk tegangan maksimum. Langkah selanjutnya menghitung Margin of Safety (MS) untuk mengevaluasi pengaruh ketebalan angle dan variasi fastener yang digunakan terhadap kekuatan strukturnya. Metodologi penelitian yang digunakan untuk penyelesaian masalah pada penelitian ini digambarkan dalam diagram alir penelitian (gambar 1).

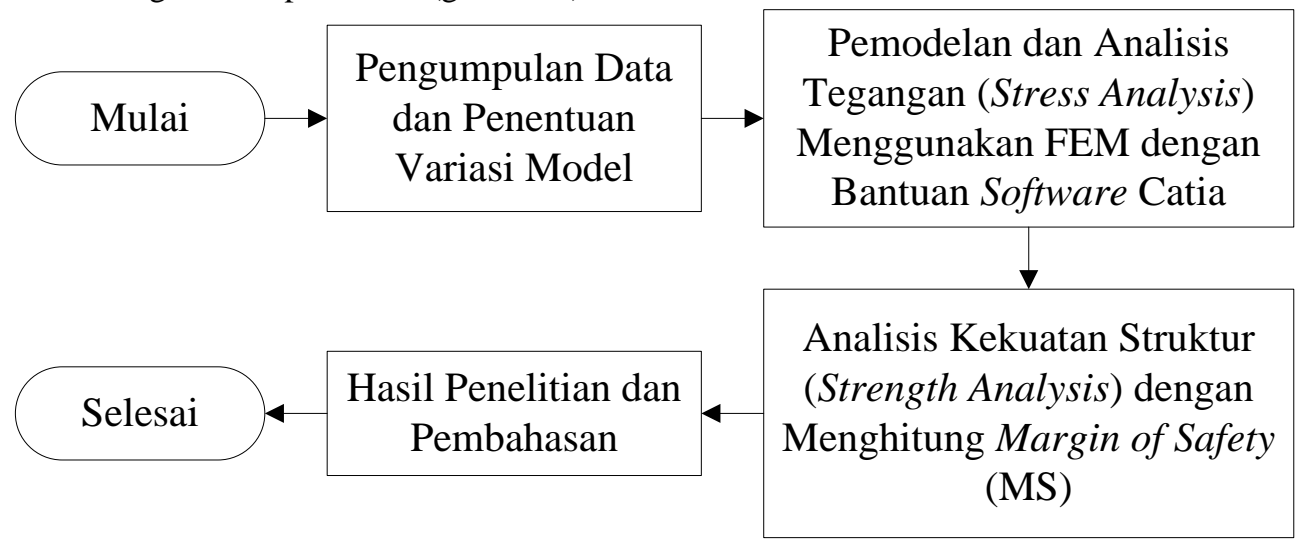

Gambar 1. Diagram Alir Penelitian

\subsection{Struktur Repair Stringer}

Pada penelitian ini struktur yang akan dimodelkan adalah struktur stringer pada fuselage pesawat B737-300 yang mengalami damage. Struktur tersebut terletak pada Section 43, Body Section (BS) 500D, Station (STA) 360 sampai 540 pada posisi stringer ST-26R (sebelah kanan). Profil repair stringer dan section atau bagian-bagiannya terlihat pada gambar 2 . 

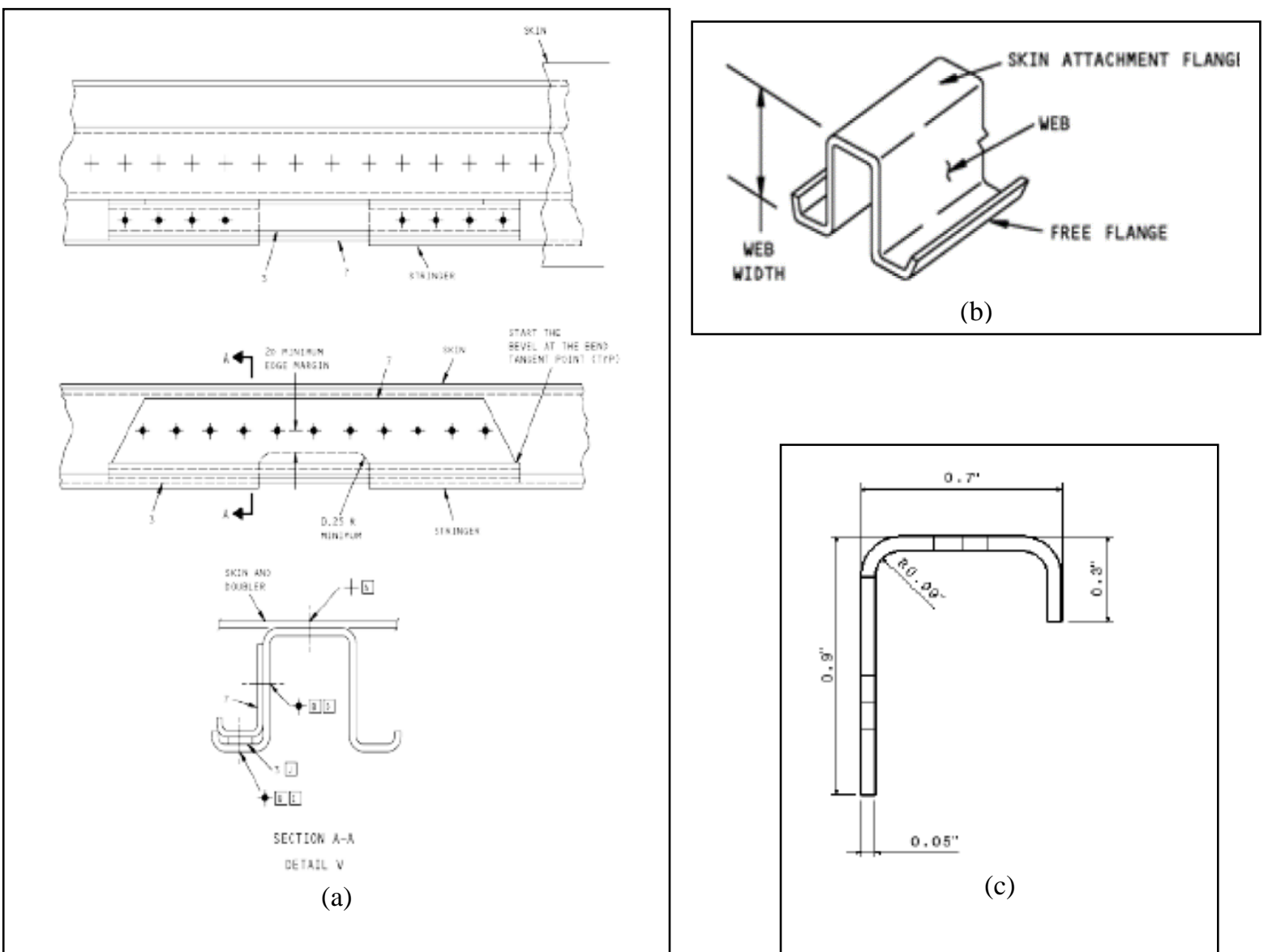

Gambar 2. (a) Profil Repair Stringer (b) Section Stringer

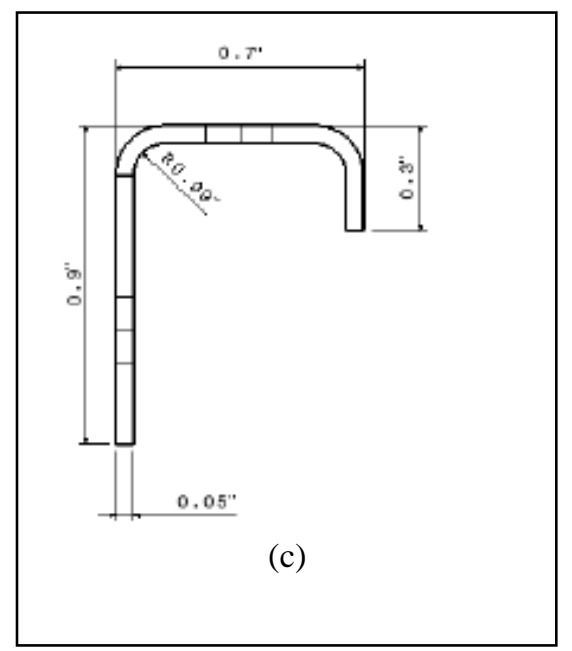

Adanya damage tersebut perlu dilakukan repair. Repair untuk stringer pada pesawat Boeing 737300 terdapat dalam SRM (Structure Repair Manual). Manual ini berisi mengenai jenis-jenis repair yang dilakukan untuk damage yang terdapat pada pesawat. Untuk repair yang dilakukan pada fuselage lebih spesifik ke stringer terdapat pada SRM 53-00-03. SRM 53-00-03 terdiri dari 3 tipe repair yaitu tipe I, tipe II dan tipe III (crown) dengan ukuran dimensi yang berbeda-beda. Pada penelitian ini menggunakan repair tipe II (gambar 3).

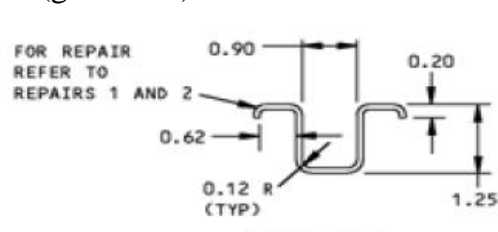

TYPE I

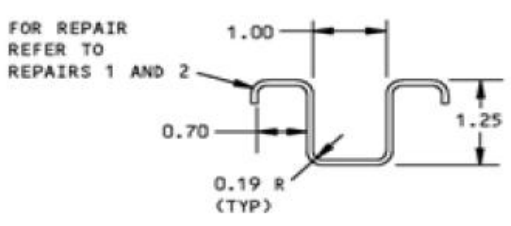

TYPE II

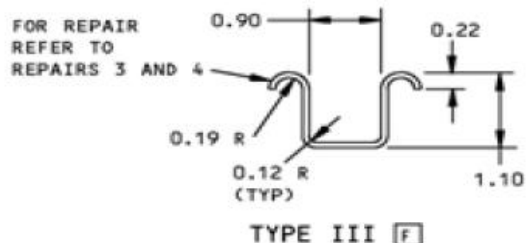

(CROWN)

Gambar 3. Tipe Repair pada Stringer [8]

\subsection{Dimensi}

Dimensi yang digunakan pada penelitian ini adalah :

1. Dimensi stringer [8]
a. Panjang
: 20 inch
b. Lebar flange area
: 0.7 inch
c. Tebal
: 0.045 inch
d. Tinggi web area
: 1.25 inch
e. Lebar skin attachment area
: 1 inch

2. Dimensi plat shim [8] 

a. Panjang
: 11.22 inch
b. Tebal
: 0.05 inch
c. Lebar
: 0.32 inch

3. Dimensi fastener MS20470 [8]

1) Flange surface
a. Diameter batang : 0.187 inch
b. Diameter head : 0.375 inch
c. Panjang : 0.145 inch

2) Web surface
a. Diameter batang : 0.187 inch
b. Diameter head : 0.375 inch
c. Panjang : 0.095 inch

4. Dimensi angle

1) Jumlah fastener 6 dan 9 pada area flange dan web
a. Panjang
: 9.35 inch
b. Tinggi web
: 0.9 inch
c. Tinggi flange
: 0.3 inch
d. Lebar
: 0.7 inch

2) Jumlah fastener 8 dan 11 pada area flange dan web, [8]
a. Panjang
: 11.22 inch
b. Tinggi web
: 0.9 inch
c. Tinggi flange
: 0.3 inch
d. Lebar
: 0.7 inch

3) Tebal angle 0.045 inch dan 0.05 inch [8]

\subsection{Variasi}

Untuk mempermudah dalam memahami variasi yang ada dalam penelitian ini, maka variasi dikelompokkan sebagai berikut:

1. Variasi 1 : jumlah fastener 8 pada flange, 11 pada web, tebal angle 0.050 inch (SRM)

2. Variasi 2 : jumlah fastener 8 pada flange, 11 pada web, tebal angle 0.045 inch

3. Variasi 3 : jumlah fastener 6 pada flange, 9 pada web, tebal angle 0.05 inch

4. Variasi 4 : jumlah fastener 6 pada flange, 9 pada web, tebal angle 0.045 inch

\subsection{Material}

Jenis material yang digunakan dan material properties dijelaskan pada tabel 1.

Tabel 1. Jenis Material dan Material Properties [9]

\begin{tabular}{|c|c|c|c|c|c|}
\hline \multirow[t]{2}{*}{ Material } & \multicolumn{4}{|c|}{ Properties } & \multirow[b]{2}{*}{ Part } \\
\hline & $\begin{array}{l}\text { Modulus Elastisitas } \\
\text { (E) }-\mathrm{N} / \mathrm{m}^{2}\end{array}$ & Poisson Ratio $(\boldsymbol{u})$ & $\begin{array}{l}\text { Densitas } \\
(\boldsymbol{\rho})-\mathrm{kg} / \mathrm{m}^{3}\end{array}$ & Yield Strength-N/m ${ }^{2}$ & \\
\hline $\begin{array}{l}\text { Alumunium } \\
\text { 7075-T6 }\end{array}$ & $7.171 \times 10^{10}$ & 0.33 & 2819.158 & $5.033 \times 10^{8}$ & Stringer \\
\hline $\begin{array}{l}\text { Alumunium } \\
\text { 2017-T4 }\end{array}$ & $7.239 \times 10^{10}$ & 0.33 & 2791.519 & $2.758 \times 10^{8}$ & $\begin{array}{l}\text { Fastener } \\
\text { MS20470 }\end{array}$ \\
\hline $\begin{array}{l}\text { Alumunium } \\
\text { 2024-O }\end{array}$ & $7.3 \times 10^{10}$ & 0.33 & 2763.88 & $7.584 \times 10^{7}$ & Angle \\
\hline $\begin{array}{c}\text { Alumunium } \\
\text { 2024-T4 }\end{array}$ & $7.3 \times 10^{10}$ & 0.33 & 2763.88 & $3.236 \times 10^{8}$ & Plat Shim \\
\hline
\end{tabular}




\subsection{Pembebanan}

Beban yang digunakan pada kasus ini adalah beban perbedaan tekanan kabin. Beban differential pressure 7.8 Psi asumsi pesawat terbang pada ketinggian $37000 \mathrm{ft}$ (menggunakan diagram monogram) dikalikan luas model sebesar 12.6 inch $^{2}$, sehingga didapat beban sebesar $98.28 \mathrm{lbf}(437.171 \mathrm{~N})$.

\subsection{Margin Of Safety (MS)}

Margin of Safety (MS) merupakan ukuran besarnya kemampuan atau kapasitas yang masih tersedia dalam suatu struktur untuk menerima beban statik secara aman pada kondisi pembebanannya. Dalam bentuk tegangan, persamaan $M S$ adalah [10]:

$$
\text { Margin of Safety }(M S)=\frac{\sigma_{\text {allow able }}}{\sigma_{\text {applied }}}-1
$$

Dimana: $\sigma_{a p p}$ (Applied Stress) $\quad=$ Tegangan yang terjadi pada struktur

$$
\sigma_{\text {all }} \text { (Allowable Stress) = Tegangan yang diijinkan }
$$

Struktur dinyatakan aman jika nilai MS berharga positif.

\section{HASIL DAN PEMBAHASAN}

\subsection{Tegangan Maksimum Von Mises dan Margin of Safety}

Pada model ini jenis pembebanannya adalah beban pressure yang dikenakan pada area Skin Attachment Surface dan jenis restraint yang digunakan adalah Clamp Surface. Pada Original Stringer (Tanpa Damage) nilai tegangan maksimum von mises adalah $6.73 \times 10^{6} \mathrm{~N} / \mathrm{m}^{2}$, terletak pada ujung surface flange stringer (gambar 4). Maka nilai margine of safety-nya adalah:

$$
M S=\frac{5.033 \times 10^{8} \frac{\mathrm{N}}{\mathrm{m}^{2}}}{6.73 \times 10^{6} \frac{\mathrm{N}}{\mathrm{m}^{2}}}-1=73.784
$$

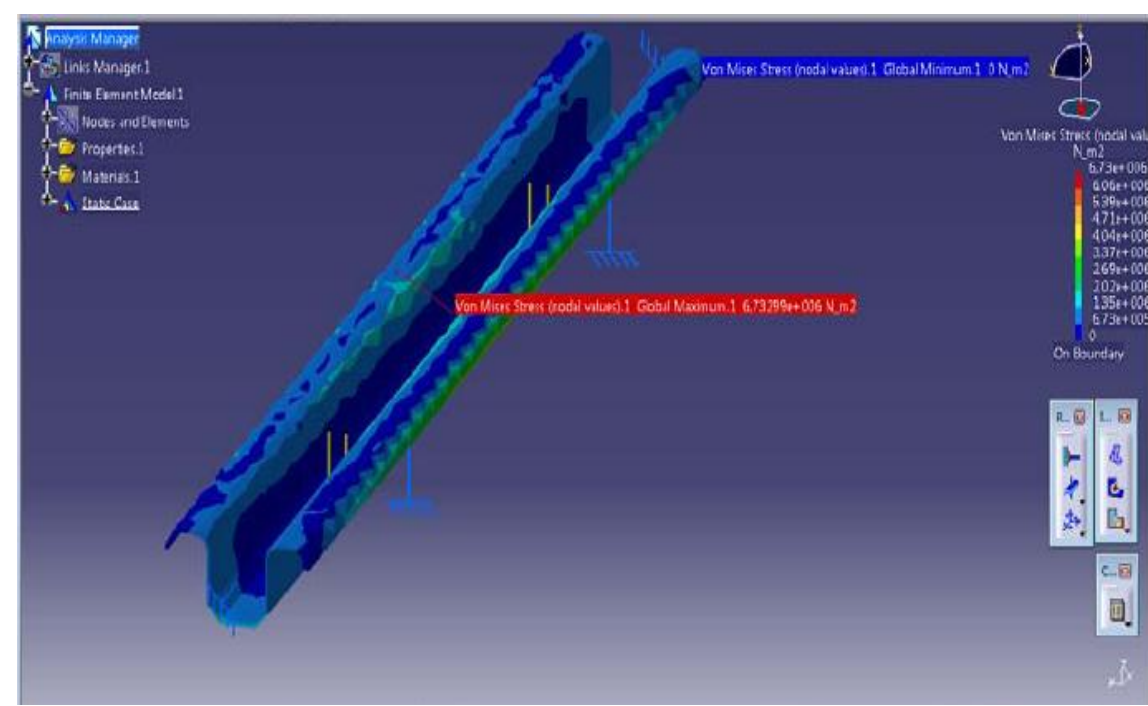

Gambar 4. Nilai Tegangan Maksimum Von Mises pada Original Stringer

(Tanpa Damage)

Pada variasi 1 tegangan maksimumnya sebesar $7.52 \times 10^{6} \mathrm{~N} / \mathrm{m}^{2}$, terletak pada bagian yang sama dengan original stringer yaitu pada bagian ujung surface flange stringer $\quad$ (gambar 5), besar nilai MS adalah 65.928 . 


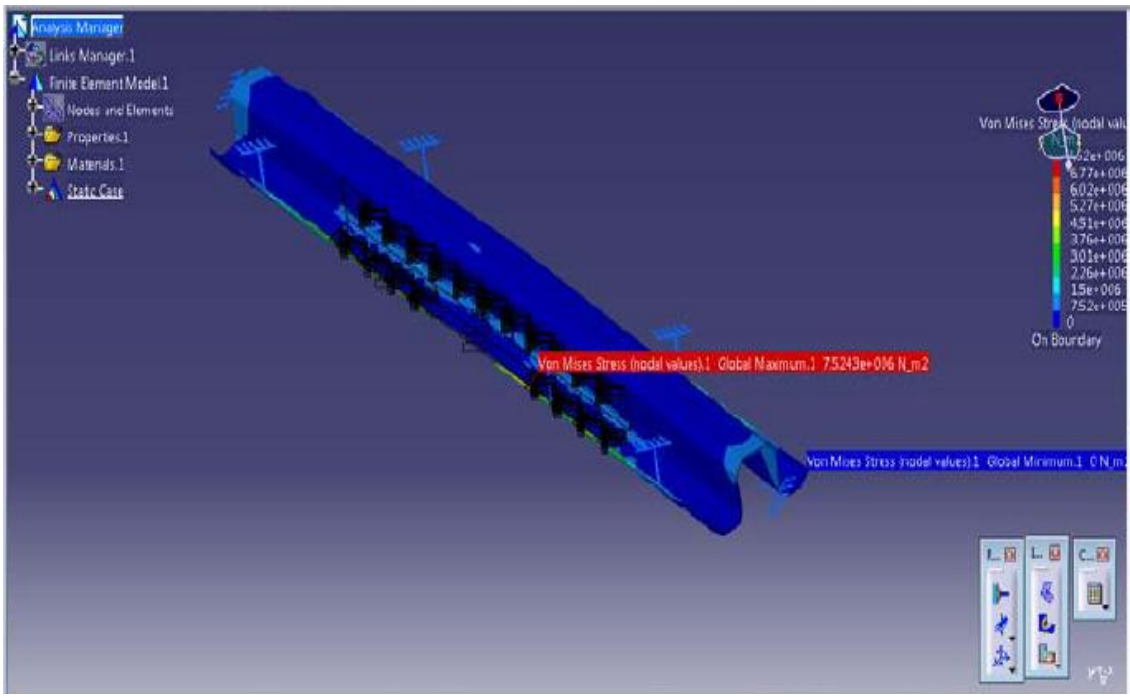

Gambar 5. Nilai Tegangan Maksimum Von Mises pada Variasi 1

Besarnya nilai tegangan maksimum dan $M S$ dari masing-masing part pada variasi 1 tercantum pada tabel 2. Nilai MS untuk semua part bernilai positif, dapat diartikan semua part aman terhadap pembebanan yang diberikan.

Tabel 2. Nilai Tegangan Maksimum dan $M S$ dari Masing-masing Part pada Variasi 1

\begin{tabular}{lccc}
\hline \multicolumn{1}{c}{ Part } & Tegangan Maksimum-N $/ \mathrm{m}^{2}$ & ${\text { Yield Strength-N } / \mathrm{m}^{2}}^{2}$ & MS \\
\hline Stringer & $7.52 \times 10^{6}$ & $5.033 \times 10^{8}$ & 65.928 \\
Shim & $7.14 \times 10^{5}$ & $3.236 \times 10^{8}$ & 452.221 \\
Angle & $1.94 \times 10^{6}$ & $7.584 \times 10^{7}$ & 38.093 \\
Fastener web & $7.29 \times 10^{5}$ & $2.758 \times 10^{8}$ & 377.326 \\
Fastener flange & $7.35 \times 10^{6}$ & $2.758 \times 10^{8}$ & 36.523 \\
\hline
\end{tabular}

Pada variasi 2 tegangan maksimumnya sebesar $8.14 \times 10^{6} \mathrm{~N} / \mathrm{m}^{2}$, terletak pada tepi flange angle (gambar 6), dengan nilai $M S$ adalah 33.882.

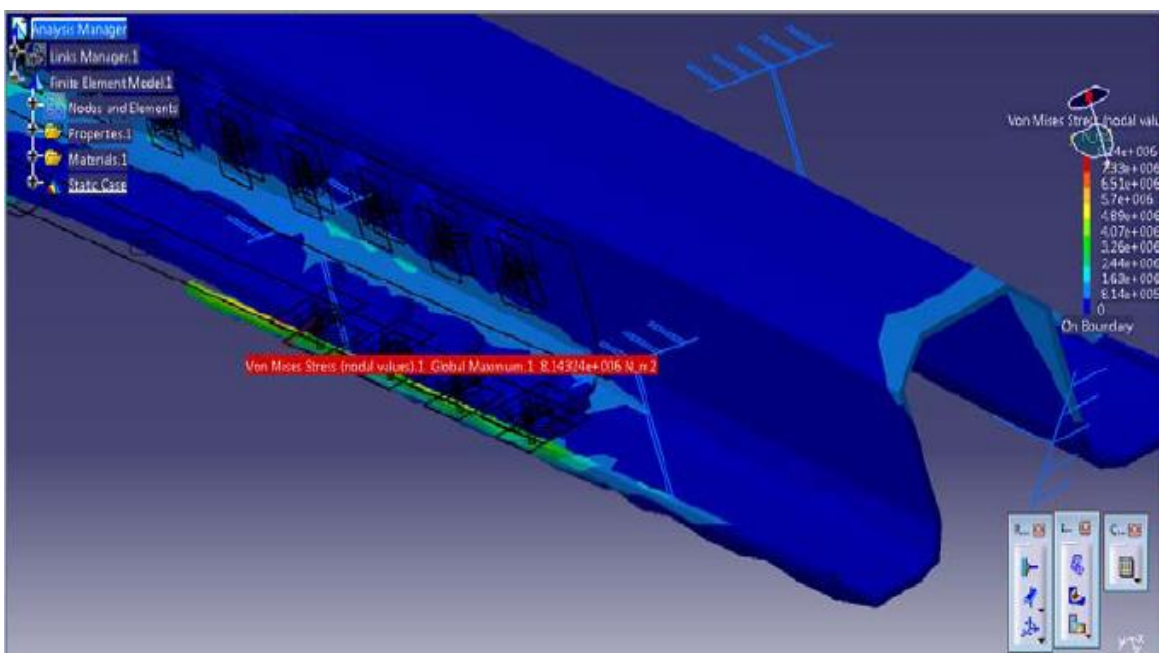

Gambar 6. Nilai Tegangan Maksimum Von Mises pada Variasi 2

Besarnya nilai tegangan maksimum dan $M S$ dari masing-masing part pada variasi 2 tercantum pada tabel 3. Nilai MS untuk semua part bernilai positif, dapat diartikan semua part aman terhadap pembebanan yang diberikan. 
Strength Analysis on Airplane Fuselage Structure Stringer

Tabel 3. Nilai Tegangan Maksimum dan MS dari Masing-masing Part pada Variasi 2

\begin{tabular}{lccc}
\hline \multicolumn{1}{c}{ Part } & Tegangan Maksimum-N $/ \mathrm{m}^{2}$ & Yield Strength-N $/ \mathrm{m}^{2}$ & MS \\
\hline Stringer & $7.54 \times 10^{6}$ & $5.033 \times 10^{8}$ & 65.751 \\
Shim & $6.53 \times 10^{5}$ & $3.236 \times 10^{8}$ & 494.559 \\
Angle & $2.04 \times 10^{6}$ & $7.584 \times 10^{7}$ & 36.176 \\
Fastener web & $7.42 \times 10^{5}$ & $2.758 \times 10^{8}$ & 370.698 \\
Fastener flange & $8.14 \times 10^{6}$ & $2.758 \times 10^{8}$ & 33.882 \\
\hline
\end{tabular}

Pada variasi 3 tegangan maksimum $8.6 \times 10^{6} \mathrm{~N} / \mathrm{m}^{2}$, terletak pada bagian yang sama dengan original stringer dan variasi 1 (gambar 7), dengan nilai MS 57.523.

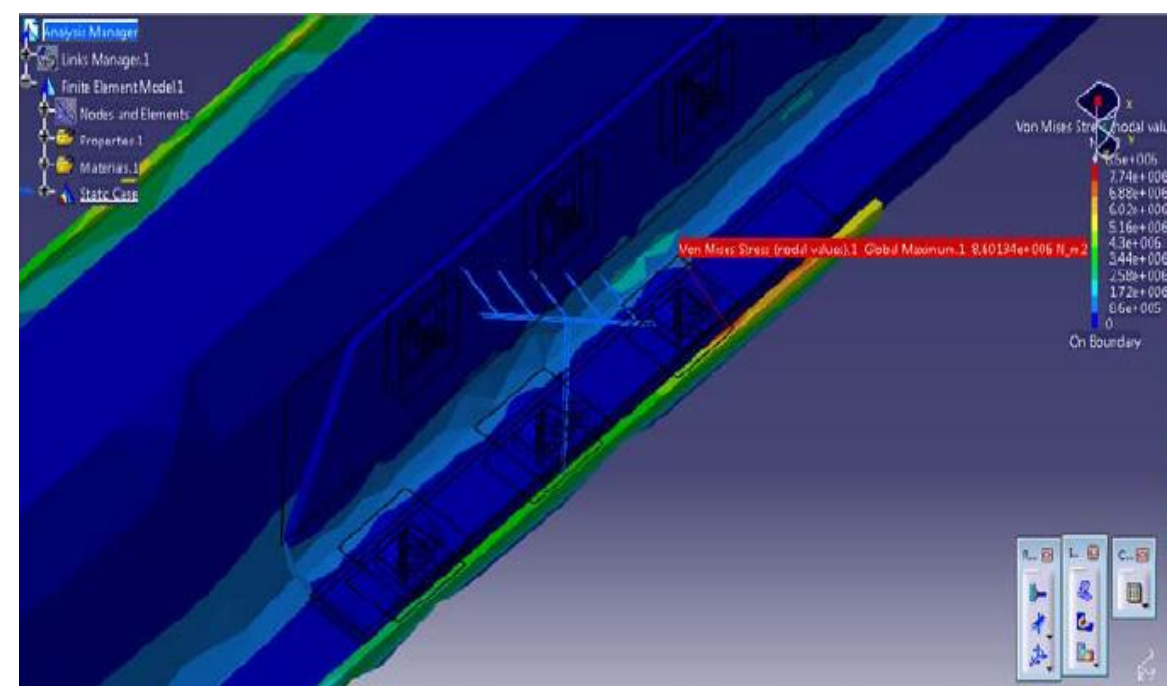

Gambar 7. Nilai Tegangan Maksimum Von Mises pada Variasi 3

Besarnya nilai tegangan maksimum dan $M S$ dari masing-masing part pada variasi 3 tercantum pada tabel 4. Nilai MS untuk semua part bernilai positif, dapat diartikan semua part aman terhadap pembebanan yang diberikan.

Tabel 4. Nilai Tegangan Maksimum dan MS dari Masing-masing Part pada Variasi 3

\begin{tabular}{lccc}
\hline \multicolumn{1}{c}{ Part } & Tegangan Maksimum-N/m ${ }^{2}$ & ${\text { Yield Strength-N } / \mathrm{m}^{2}}^{2}$ & MS \\
\hline Stringer & $\mathbf{8 . 6 \times \mathbf { 1 0 } ^ { \mathbf { 6 } }}$ & $5.033 \times 10^{8}$ & 57.523 \\
Shim & $6.35 \times 10^{5}$ & $3.236 \times 10^{8}$ & 508.606 \\
Angle & $2.28 \times 10^{6}$ & $7.584 \times 10^{7}$ & 32.263 \\
Fastener Web & $5.15 \times 10^{5}$ & $2.758 \times 10^{8}$ & 534.534 \\
Fastener flange & $4.21 \times 10^{6}$ & $2.758 \times 10^{8}$ & 64.511 \\
\hline
\end{tabular}

Sedangkan variasi 4 tegangan maksimum $8.72 \times 10^{6} \mathrm{~N} / \mathrm{m}^{2}$, terletak pada bagian yang sama dengan original stringer, variasi 1 dan 3 (gambar 8), dengan nilai MS 56.717. 


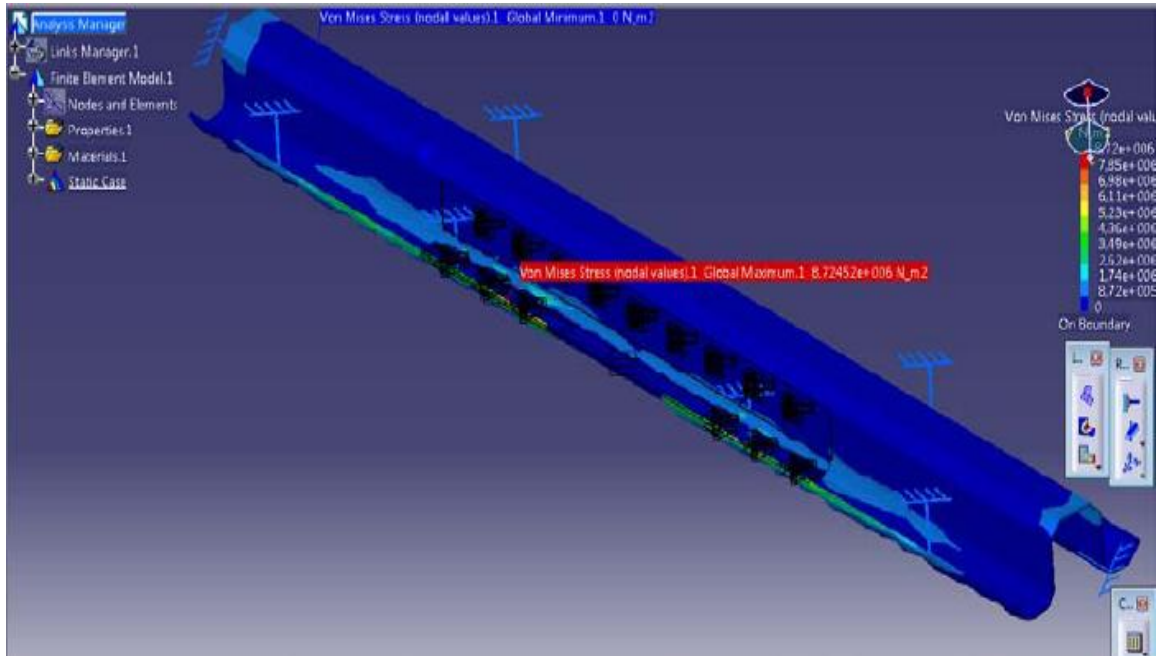

Gambar 8. Nilai Tegangan Maksimum Von Mises pada Variasi 4

Besarnya nilai tegangan maksimum dan $M S$ dari masing-masing part variasi 4 tercantum pada tabel 5. Nilai MS untuk semua part bernilai positif, dapat diartikan semua part aman terhadap pembebanan yang diberikan.

Tabel 5. Nilai Tegangan Maksimum dan $M S$ dari Masing-masing Part pada Variasi 4

\begin{tabular}{lccc}
\hline \multicolumn{1}{c}{ Part } & Tegangan Maksimum-N $/ \mathrm{m}^{2}$ & Yield Strength-N $/ \mathrm{m}^{2}$ & MS \\
\hline Stringer & $\mathbf{8 . 7 2} \times \mathbf{1 0}^{\mathbf{6}}$ & $5.033 \times 10^{8}$ & 56.717 \\
Shim & $6.06 \times 10^{5}$ & $3.236 \times 10^{8}$ & 532.993 \\
Angle & $2.79 \times 10^{6}$ & $7.584 \times 10^{7}$ & 26.182 \\
Fastener Web & $5.28 \times 10^{5}$ & $2.758 \times 10^{8}$ & 521.348 \\
Fastener flange & $4.61 \times 10^{6}$ & $2.758 \times 10^{8}$ & 58.826 \\
\hline
\end{tabular}

\subsection{Pengaruh Ketebalan Angle dan Jumlah Fastener terhadap Tegangan Maksimum}

Berdasarkan tabel 6, variasi 1 (variasi SRM) memiliki nilai tegangan maksimum paling kecil, sehingga nilai MSnya paling besar. Ini menunjukkan bahwa repair yang terdapat dalam Structure Repair Manual (SRM) yang dikeluarkan oleh Boeing sangat aman dan kuat jika dibandingkan dengan variasi lainnya. Dan perbandingan repair dalam SRM dengan Original Stringer (tanpa damage) tidak begitu jauh nilai MS-nya. Secara keseluruhan struktur keempat variasi aman terhadap beban yang ditunjukkan nilai $M S$ positif.

Tabel 6. Tegangan Maksimum dan $M S$ untuk Semua Variasi

\begin{tabular}{ccc}
\hline Specimen Stringer & Tegangan Maksimum-N/m $\mathrm{m}^{2}$ & MS \\
\hline Original Stringer & $6.73 \times 10^{6}$ & 73.784 \\
Variasi 1 (SRM) & $7.52 \times 10^{6}$ & 65.928 \\
Variasi 2 & $8.14 \times 10^{6}$ & 60.830 \\
Variasi 3 & $8.6 \times 10^{6}$ & 57.523 \\
Variasi 4 & $8.72 \times 10^{6}$ & 56.717 \\
\hline
\end{tabular}

Berdasarkan gambar 9, terlihat bahwa semakin tebal dimensi angle maka tegangan yang terjadi pada struktur repair stringer semua variasi tersebut akan cenderung turun. Penggunaan jumlah fastener yang lebih banyak (variasi 1 dan 2) juga menunjukkan turunnya tegangan akibat beban pressure. 


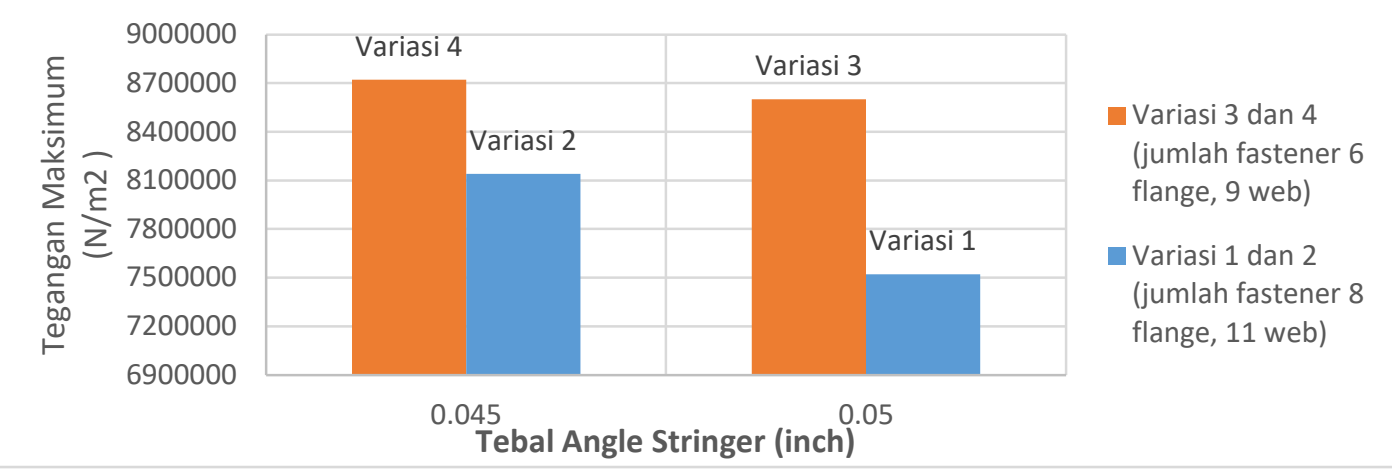

Gambar 9. Grafik Ketebalan Angle dan Jumlah Fastener terhadap Tegangan Maksimum

\section{KESIMPULAN}

Dari hasil analisis yang dilakukan pada penelitian ini, diperoleh kesimpulan sebagai berikut :

1. Struktur pemodelan repair stringer aman terhadap pembebanan pressure berdasarkan nilai margin safety.

2. Penggunaan angle yang lebih tebal dan semakin banyak jumlah fastener yang digunakan pada struktur repair stringer akan menurunkan tegangan yang terjadi, sehingga kekuatan strukturnya menjadi lebih baik.

\section{DAFTAR PUSTAKA}

[1] E. Bruhn, Analysis and design of Flight Vehicle Structures.

[2] Vasudev H, Rangaswamy H, Imran Ali MR. (2015). Structural Analysis and Material Optimization of Aircraft Fuselage, International Journal of Ignited Minds (IJIMIINDS), Vol. 2, Issue 5.

[3] Srilaxmi, Olem Prashanth Rao, Satyanarayana Gupta. (2016). Design and Static Stress Analysis of Fuselage Structure for a Military Transport Aircraft, International Journal \& Magazine of Engineering, Technology, Management and Research (IJMETMR), Vol. 3, Issue 9.

[4] Prakash, Udaya R, et.al. (2016). Structural Analysis of Aircraft Fuselage Splice Joint, IOP Conference Series : Matrial Science ad Engineering.

[5] Shreennaga, Vishwash B, Mallikappa. (2017). Adaptive Design and Finite Element Analysis of Fuselage Floor Beam of an Aircraft, International Journal of Engineering Science \& Management (IJESM).

[6] Dandekar, Aditya Milind, 2017. Finite Element Analysis of Composite Aircraft Fuselage Frame. Thesis. The University of Texas at Arlington.

[7] Saeed, Isaac N, 2017. An Investigation of Semi-Monocoque Aircraft Strutural Design with a Detailed Evaluation of Primary Structure Member Stability Criterion. Thesis. California State Polytechnic University.

[8] Boeing 737-300, Structure Repair Manual, Chapter 53-00-03.

[9] http://asm.matweb.com

[10] Niu, M.C.Y. (1997). Airframe Stress Analysis and Sizing (p.795). Hong Kong: Conmilit Press. 
